\title{
THE PROBLEMS ASSOCIATED WITH STUDYING FOLK VERSE
}

\author{
Jury Paciupa \\ Center for Belarusian Culture, Language and Literature Research \\ National Academy of Sciences, Belarus \\ e-mail:paciupa@gmail.com
}

\begin{abstract}
The article studies the problem of internal mechanisms of folk verse. An approach that is based on the universals of rhythm, where a verse is described with due account for levels (syllable, syntagma and phrase), is offered. As the basic element of the verse, colons, the invariant structure of which is determined by the law of regressive accentual dissimilation, is considered. A set of stanzas of folk verse seems to be a combination of invariants: archritmemas and their modifications, the prototypes of which can be observed in interjections and echoism. Prose-centeredness (prose is normal, while verse is an anomaly) is criticized. The author suggests a system of coding for invariants of folk verse and illustrates it with a number of examples. In the conclusion, the issue of reconstruction of the ancient state of the verse is touched upon, with due consideration of the universals of rhythm, and the problem of areal description for the forms of folk verse.
\end{abstract}

Keywords: accentual, anapaest, archritmema, caesura, clausula, colon, a constant, dactyl, iamb, ictus, measure, rhythm, ritmema, strophe, syllabic, trochee, a universal, verse

\section{INTRODUCTION}

We still do not know anything about how folk verse functions: how it emerges, develops, or what it is based on. The same thing could be said about a literary poem, but there is no recognition of the fact that literary poems have not been studied. Vice versa, there is a feeling of exhaustiveness of the rules of versification, and the science of versification on the whole. In one of his last works, Gasparov claimed quite seriously: "The four fields - metrics, the rhythm system, rhyme, and strophe - have been developed so well that no revolutions are expected there in the near future" (Gasparov \& Skulacheva 2004: 11). Why can these words not also refer to the popular verse? Not only because it has not been described in a sufficiently extensive way. There is no theory of popular verse, even for a first approximation, which would be satisfactory for everyone 
to the extent which is observed in literature. The difference can be explained in a very easy way: The theory for literary verse consists in the rules of versemaking, orthometrics, while popular verse exists without any rules one way or the other, which desires an explanation.

In recent years, from the moment of the first experience of dealing with popular verse (Paciupa 2014), I have developed a theory of the verse in bare outlines, which continues my own previous research (Paciupa 2004) and synthesizes the conclusions made by verse researchers belonging to very different schools, which sometimes contradict each other, above all Potebnya (1884), Kvyatkovskiy (1966, 2008), and Taranovskiy $(2000,2010)$, and in certain aspects I rely on individual ideas and discoveries made by Chudovskiy $(1915,1917)$, Tomashevskiy (1959), Chukovskiy (2001 [1928]), Yanakiev (1960), Timofeyeva (1958, 1987), and Beyli (2001). For a review of my findings, I refer you to my publications (Paciupa 2014, 2014-2016, 2016). In this article, I summarize and uncover the experience of studying popular versification through a number of examples. The understanding of the verse is based on the universals of rhythm and seems to be relevant, at least, for any language that has an expiratory accent.

The purpose of the article is to reveal rhythmical universals of popular verse and create a system of coding for its invariants, which would allow poetic texts to be compared and described in the aerial and time perspective. The following issues should be addressed while pursuing the main goal: 1) brief theoretical basis of the principles of popular verse; 2) analysis of linguistic phenomena, in which rhythmical universals are observed; 3) a description of the system for coding invariants and illustrating it with examples from Belarusian folk poetry; 4) considering the perspectives of using the suggested system. In this article, the invariant-genetic approach to the verse phenomena was used, conclusions were made on the basis of observations over linguistic facts and the phenomena of popular verse, and for a more fundamental understanding of rhythmical processes, comparisons with well-known phenomena in other national traditions were made, both close and distant ones. As an introduction, let us recall a number of critical judgements which were exercised by renowned linguists, but were never taken seriously.

If the statement that "the accuracy of classification determines the accuracy of further studies" is true (Propp 2001: 7), the opposite is also true. In 1923, Yakobson wrote:

The current division of verses into accentual, syllabic, and metrical is inefficient and inaccurate. The unity of the signs of division is not observed. While the accentual principle means a certain way of exercising a strong beat, 'syllabism' only means the measure of the length of a poem or a rhythmical segment; a syllabic verse can be both metrical (Vedic) or 
accentual at the same time, and such syllabic-accentual verse can also have syllabic segments (Russ. <кuü> verse, 19th cent.) or do without them. (Yakobson 1923: 46)

Neither of the "systems" holds up against criticism from the inside either. For example, a "syllabic" verse, unlike some subtypes of "accentual" verse, really exists. It is the oldest type of verse which lies at the origins of not every, but definitely of an overwhelming majority of national traditions. But it is provided with a completely mythical interpretation, in accordance with the name, except for the accentual aspect. Meanwhile, it was Polivanov who wrote the following:

A pure incident of syllabic versification, i.e., the type of versification that is based exclusively on the aspect of the number of syllables in the corresponding parts of speech (verses), free from the accentual aspect, can be found in just a few languages. (Polivanov 1963: 106)

As for "accentual" verse, the term itself is accurate but has no sense - within the scope of the effect of expiratory accent, all verses are accentual one way or another. This being said, some accentual verses in truth turn out to be pentons ("dolnik") (Paciupa 2014-2016, № 11: 23), while the measure of other "accentual verses" is irrational (Shtokmar 1952b).

As the experience of describing verse in very different languages, especially in languages that have recently acquired national attributes (which do not have standardized rules) and even more so, popular verse, has confirmed, reducing it to an unambiguous definition, a well-known "system of versification" is fraught with difficulty. As it has been rightfully pointed out by Tudenov:

In almost all studies of folklore versification or the poetry of a transition period, an obtrusive tendency for looking for one or another common means for rhythm-making is observed, which aims at fitting all of the multiform rhythmical verse-making processes into Procrustean bed, i.e. the frameworks of the existing systems. ... In our opinion, the rhythm of folk verse is set not by a single metrical tool, but by the whole set of metrical means that are used in different national traditions. (Tudenov 1958: 84-85)

\section{LEVELS OF SPEECH AND MECHANICS OF VERSE}

Before addressing the facts, the following aspects should be taken into consideration. Firstly, there are two principles of organization of verse, syllabic and accentual, which are correlated differently in different languages, but neither of them should be completely ignored. Secondly, different levels 
should be distinguished in any poetic text: syllabic, syntagmic, and phrasal, which are correlated with the categories of poetics: syllable, colon, and period. In folk verse, speech and poetic segmentation match almost completely because of the lack of such a phenomenon as enjambment. The element of the most basic verse unit is a colon. Colons have internal structure that is measured by feet, and are united into a system - a period and a strophe (Fig. 1). A foot is an integrant, but not an element of a verse: if we compare colons with elementary particles, feet can be compared with quarks that are impossible to be isolated as individual units. The structural standing point of a colon is a constant, i.e., a final stressed syllable that corresponds to the syntagmatic stress (Fig. 2). Strong stances in the colon are distributed from the constant to the beginning of the verse, in conformity with the law of regressive accentual dissimilation (RAD) (Taranovskiy 2000: 274-282), which determines the invariant of a colon - a ritmema (see the paradigm of ritmems in Fig. 3).

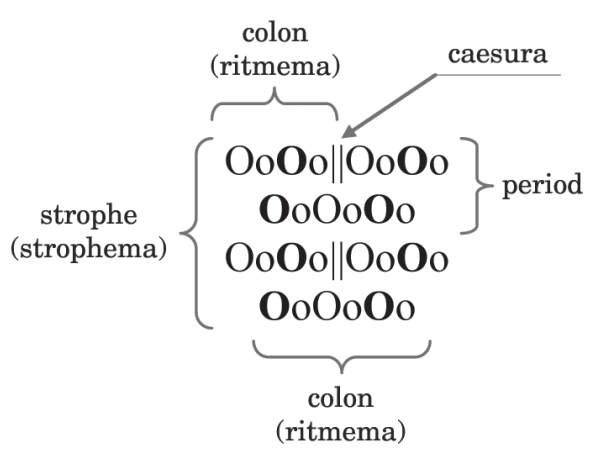

Figure 1. Structure of the strophema $[2(\boldsymbol{a}+\boldsymbol{a}+\boldsymbol{\beta})]$.

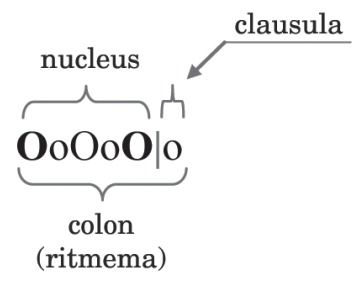

Figure 2. Structure of a colon (archeritmema $\boldsymbol{\beta}$ ). 


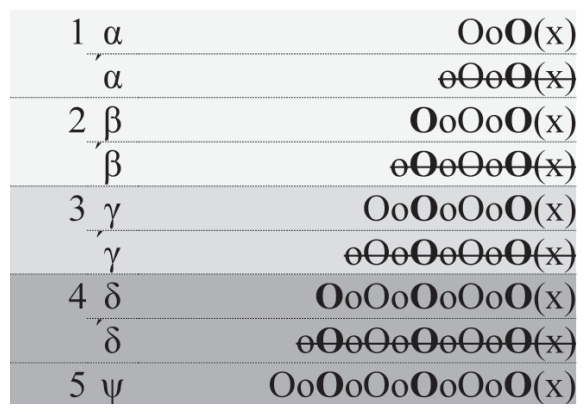

Figure 3. Paradigm of ritmemas (archeritmemas and hyperritmemas).

RAD is a resultant of more basic laws: the law of the final localization of the constant (LC) and the law of the distancing of accents (DA), which was well known to Vostokov and Samsonov (Vostokov 1817: 21-22; Samsonov 1817: 226). In accordance with the latter law, two ictuses cannot stand next to each other, which means that there is no such foot as a "spondee". However, if two accents turn out to be next to each other, one of them is deaccentuated and is no longer an ictus (óó), or there is a caesura (ó||ó) or leymah (ó/\ó) between ictuses. As Taranovskiy wrote later: "A dynamic accent should have two 'inclines' (i.e., a certain number of unstressed syllables before and after it) in order to be more pronounced" (Taranovskiy 2010: 540). Therefore, RAD is a consequence of an expiratory (dynamic) accent, and it manifests itself locally even in trisyllabic meters, for example, in anacrusis anapaest (Paciupa 2004: 308-309). Let us describe how, as a result of interaction between the LC and the DA, the RAD emerges, and then demonstrate this process directly on language facts and indirectly in folklore poetics.

From the DA, it follows that a constant does not tolerate any kind of stress right next to it, and if the stress does appear, it is deaccentuated. And now let us imagine this in motion: taking the constant as a baseline, we move from the end of the colon to the beginning of it. The third syllable allows stress, but a much weaker one. In texts, we most often observe the absence of stress here, or the "abandoned" stress, as Chudovskiy (1917: 63) calls it. Then an unstressed syllable follows, and on the fifth syllable a stress appears, which is more pronounced than on the third one, but is weaker than on the first syllable (i.e., weaker than the constant). This motion never stops until it reaches the beginning of the colon. The sequence of alternations may be different only if two (trisyllabic meters) or four unstressed syllables (pentons) will in some way consistently be forced between stressed syllables. However, trisyllabic meters and pentons are not generated on their own, and if they are, only under specific conditions and within specific limits, which will be discussed below. 
Thus the RAD phenomenon, discovered by Taranovskiy (2000: 275), anticipated by Chudovskiy (1917: 60-63), and to some extent even earlier than that by Kulakovskiy (1890: 2), is not limited to a certain historical period. The "frame" rhythm that does not go along with the RAD has always been an abnormality and never - even in the eighteenth century, when it was mostly used in literary iambic verses - predominated. In folklore, "paeons" were most often detected (Samsonov 1817: 251; Dubenskiy 1828: 55-88) - this is how the RAD was described in terms of metrics. What also matters here is that both the syllabic and the accentual framings form a single whole, where the leading part belongs to the syllabism: the actual number of syllables in the colon, counting from the constant, determines the potential structure - the ritmema.

The ritmema, no matter how we see it - as an effect of the RAD, according to Taranosvkiy, or as an alternating rhythm, according to Tomashevskiy (1959: 41-56), or by means of "check rows" suggested by Kvyatkovskiy (2008: 545-547), or, eventually, as an ancient dipody or as a paeon, observed by Samsonov and Dubenskiy - in any case, it is trimetric, not dimetric. The ritmema contains an alternation of alternations: firstly, ictuses and unstressed syllables alternate, and, secondly, strong (mandatory) and weak (nonmandatory) ictuses alternate too. This surge of alternations, or "a more complex metric unit" (Alandskiy 1875: 81), if you wish, can be called an actual foot, while the feet that are usually used, such as iambic, trochaic, and paeonic feet, always simplify the rhythmic space. They are like the Cartesian coordinate system, like a scale system, external to the object. This is why it is strongly recommended to use both the iambic-trochaic and the paeonic scales in parallel. It is paradoxical, but it has turned out to be equally useful to reject a foot in literature (Chudovskiy 1915: 60), i.e., where it has been expected, and to implement it in folklore (Beyli 2001: 27-78, 386-398), where it has seemed inconceivable. Every single theory has its due time.

The absolutization of one of the principles of the organization of a verse led to the emergence of a number of competing theories of folk verse in the nineteenth century: foot, accentual, syntactic, and musical theories (see Shtokmar 1952a: 17-135), which, as had been pointed out by Taranovskiy, were not antagonistic, but complementary (Taranovskiy 2010: 520-522). The basic element of a verse - the colon - was referred to as a "prosodic period" by Vostokov (1817) and as a "syntactic foot" by Potebnya (1884), which led not only to a confusion of notions, but also to the elimination of the perception of the hierarchical organization of versified speech as it is. Perhaps it was only the musical theory (the most erroneous, by the way) that was not at fault in this case and divided the levels of verse structure. But the tendency for planar perception of a verse, which does not take into consideration either the hierarchical structure of 
a verse text or the trimetric development of the rhythm, is still alive, and it has even been flourishing. This reductive trend is alive in the interval theory of the accentual verse ("dolnik", "taktovik", "purely accentual”), which is the continuation of the school metrics and goes back, perhaps, to Trediakovskiy, who pronounced a verdict on the colon: “сии члены не стихи” (these members of a sentence are not a verse) (Trediakovskiy 2002: 110).

\section{INTERJECTIONS AND RHYTHM UNIVERSALS}

However, in the nineteenth and twentieth centuries, through joint efforts of folklorists, poetry researchers, and linguists, massive factual material was collected. And if we disengage ourselves from individual theoretical discrepancies, it can be said that we are dealing with a quite full perception of the structure and the main forms of the Slavic folk verse, which enables us to reconstruct its development against the background of the development of the Indo-European and panhuman verse. The basic forms of the Belarusian and, more widely, the Slavic folk verse are $8+8,6+6,5+5,8+6$, etc. The combinations of five and six syllables are not divided into smaller elements, while the combinations of eight syllables are divided into $4+4$ or $5+3$. However, the links between these smaller colons are stronger than between large ones, while, on the opposite, the caesuras between them are less clear. These combinations give rise to such phenomena as 8 -syllabic ( $4+4$ and 5+3), 10-syllabic (5+5 and 3+6), 12-syllabic $(6+6$ and 4+4+4), 14-syllabic (8+6), which are known as "syllabic verse", either folk or literary. They constitute the main stock of the proto-Slavic verse (Ivanov \& Toporov 1963). However, such forms occur in Turkic, Mongolian, Finno-Ugric, Caucasian, and other languages, not to mention Indo-European ones. Why do such combinations predominate, and what do they have in common?

If we have a close look not only at the number of syllables in the colon, but also at the localization of the constant, we will notice a consistent pattern: in the colons with the even numbers of syllables, the constant is usually on a next-to-last syllable, while in the colons with the odd number - on the last syllable, which is why the nucleus (i.e., all syllables in the colon or its lines, except for the clausula (Fig. 2)), is initially of two types only - 3-syllabic and 5-syllabic ( $\mathrm{OoO}$ or $\mathbf{O o O o O})$. The 7-syllabic nucleus of an 8-syllabic verse also genetically comes down to these structures. However, most often, 8-syllabic verses are divided into colons in synchrony too: $4+4$ or $5+3$. If the nucleus is 3 or 5 syllables long, and the RAD law applies invariably, there can be no other rhythm except for trochaic. But as soon as the length of the nucleus changes, the trochee disappears (the last example in the article represents a modified 
ritmema of this kind). In order to assure ourselves of the assumptions that have been made and see the interrelation between the length of the nucleus and the structure of the ritmema, perfect conditions are required, under which every single syllable could have a potential of being an ictus, because it stands in the strong position - under the stress. Fortunately, such conditions exist virtually in all world languages, namely in exclamations and onomatopoeias, which will serve us as a "perfect" model for observation.

Let us reproduce a knock at the door: tuk-tuk, the clock ticking: cik-tak; a cuckoo calling: $k u-k u$; and some other similar sounds: buĺ-bul, kap-kap, haŭhaŭ, miaŭ-miaŭ, roch-roch, oj-oj, lia-lia, tak-siak. In every single case of a twopart, complete or incomplete, reduplication of 1-syllable words a stronger stress falls on the last syllable: tuk-túk. This peculiarity is also observed in such words as ki-hi, ku-ha, ču-fy, kuldyk, baŭbyć, šturchiel, čyryk, šarach. The position of stress is not dependent on the nature of vowel sounds or their setting. Of course, you can say it the other way round: túk-tuk, but you will have to make conscious effort to do that. One way or another, the stress in the preposition will always sound less natural. We can say: with formal equality of stressed syllables, a stronger stress falls upon the last syllable. The obtained result verifies a common law: in a neutral style, syntagmatic and phrasal stresses are at the end (Kodzasov \& Krivnova 2001: 386; Bondarko \& Verbitskaia \& Gordina 1991: 116-117). Verse obeys the same LC law. We can abstract our minds from what the onomatopoeia will be - a syntagma (tuk-tuk), a word ( $k u l d y k)$ or a "word-phrase". However, if we change experimental conditions and emphasize both components to a considerable degree: túk - túk; káp - káp, we will observe something like a pause between the two words, which means that the DA law comes into play here. However, it is still too early to make any kind of conclusions on the basis of what we have just seen.

Let us have a look at similar three-syllable combinations: tuk-tuk-tuk, kapkap-kap, haŭ-haŭ-haŭ, ach-ach-ach, o-jo-joj, o-ho-ho, o-cho-cho, u-cha-cha, tra-ta-ta, nu-i-nu, ta-ra-rach, ty-li-li, ciu-liu-liu, čyk-čyryk, šabultych, ku-klusklan. The accents are also distributed in a certain sequence here: túk-tuk-túk, káp-kap-káp, ó-jo-jój! The strongest syllable is always the last one, which is always stressed, but there is a clear stress on the first syllable, too. (In fact, the nature of accentuation of the first and the last syllables is different, which is especially noticeable on the example of such onomatopoeia as $i$-ho-hō!, where the voice goes up on the first syllable, and the syllable becomes stronger, while on the last syllable it becomes longer and stronger. But we abstract our minds from the nature of accents.) The second syllable, which is right in the middle, sounds as if it is not stressed at all. Even if we make a conscious effort, it is much more difficult to shift the stress to the second syllable than to the first 
one in a two-syllable composition. Thus we are witnessing the alternation of the intensity of pronunciation with formal identity of syllables, i.e., we get the rhythm that can be interpreted as trochaic. It is extremely important that it inevitably emerges outside of the opposition "verse/prose".

Now let us turn to longer combinations, trying to say them fluently, without any breaks. In order not to get confused with their number, you can record every single syllable on paper with a pencil. This time we have five syllables: $t u k$-tuk-

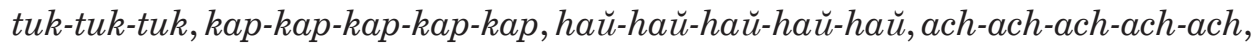
o-jo-jo-jo-joj! And once again, there is a strong accent at the beginning and at the end of a syntagma, and a less pronounced one in the middle: túk-tuk-túktuk-túk. We can hear a similar rhythm in the folk lullaby refrain: $\boldsymbol{a}^{\prime}-\boldsymbol{a}-a^{\prime}-a-\boldsymbol{a}^{\prime} / /$ $\boldsymbol{a}^{\prime}-a-a^{\prime}-a-\boldsymbol{a}^{\prime}$. In other words, there are three ictuses per five syllables. In $3-$ and 5 -syllable combinations stressed positions are distributed in a way that the first ictus always falls on the first syllable. It gives us a trochaic cadence, but any trochee can also be interpreted as a paeon, and under certain conditions also as an anapaest (see Paciupa 2014-2016, № 11: 20-23), i.e., meter is not an immanent property of the text, but a conventional scale. If exclamations and onomatopoeias are said without pauses, there are no deviations from the sequence described above. Exceptions may only occur when particles or suffixes are attached to exclamations, which, as a rule, are unstressed: avochci! nu-tka! ojeńki!, the Russian oy li!, etc. This exception proves the rule.

At the beginning of the twentieth century, Chudovskiy explained why this happens: "In a sense, I am ready to determine the most versified speech as the speech that is easy to say. Rhythmics is all about saving your voice" (Chudovskiy 1915: 83). Or, as contemporary phonetics teaches us: "The alternation of strong and weak stresses is more convenient than the vicinity of the ones with equal effect" (Kodzasov \& Krivnova 2001: 386). However, this is not merely the alternation, but the alternation within the limits of a certain syllabic structure, in which the trochee-type rhythm is inevitable under given conditions. The invariable presence of trochee in folklore is not the influence of literature, as it was assumed by Vostokov (1817), but rather the other way round. Beyli was right: "Its emergence should not necessarily be ascribed to the influence of literary verse" (Beyli 2001: 151). Some similarity to verse is also observed in the ontogenesis of speech: "It is still in the cradle, while not being able to talk yet, a baby who is eight or nine months old is happily uttering some rhythmical babbling" (Chukovskiy 2001 [1928]: 276). And it is trochee-type structures that are predominant: "Very boldly, without lengthy considerations, little children break down any kind of word form in order to secure the victory of their favorite rhythm" (ibid.: 285). 


\section{THE SYSTEM OF RHYTHMIC FORMS CODING}

So, the following structures are observed in exclamations and onomatopoeias the three stages of rhythm generation - a monad: $\mathbf{O}$ (one ictus); a diad: oO (two syllables and one ictus); a triad: OoO (three syllables and two ictuses), and

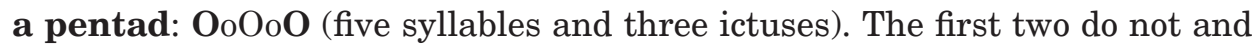
cannot contain within themselves any kind of rhythm measure - a rhythmicity (periodicity of some kind or recurrence, as Kvyatkovskiy would have put it). Only the last two are the minimum rhythm units with a 2 -syllable (weak ictuses) and a 4-syllable (strong ictuses) alternation range, or, in other words, the reification of a ritmema. Incidentally, a 3-syllable unit is not quite independent either, because it does not accommodate the full rhythmic cycle of the RAD: from the constant (as a strong ictus), bypassing the middle one - to the strong ictus, but only half of the cycle: from the constant - to the middle ictus. Tomashevskiy noticed the rhythmical dependence of commas - small colons (Tomashevskiy 1959: 23), while Kvyatkovskiy made a number of important conclusions for his theory on the basis of this phenomenon (Kvyatkovskiy 1966: 364, 96, 64).

Traditional folk verse comes down to the combinations of colons with 3 - and 5 -syllabic nuclei or goes up to them. This phenomenon is not only verified by the facts from Belarusian folklore. However, I will not decide on the generality of it and will refrain from further generalizations. It can only be pointed out in advance that certain exceptions are monosyllabic languages. In such languages, regardless of the nature of stress, syllable monads and diads serve as construction material: "The initial measure of the Vietnamese verse is a bar (tyet), which usually consists of two syllables (sometimes from three syllables or from one syllable). ... Syllable tones do not alternate one after another, but the tones of the last syllables in bars" (Yan 1976: 101). Obviously, a bar here is something equal to a foot if the number of syllables is taken into account, or even a smaller unit, while it is equal to a colon if the level is taken into account. In European languages, a verse cannot be made up of 1- or 2-syllable commas, because they agglutinate into larger colons, even in such literary contrivances as brachy-colons (see Kvyatkovskiy 1966: 64-65).

We can regard the sequence of structures oO (tuk-tuk) as the iamb, but it will not be an iamb, just like it is not an iamb in the Khmer language, which has expiratory accent, by the way. Feet are the integrants of colons, which are not divided by caesuras, like the latter, and are impossible to single out without ruining the word. The question arises as to what is primal - syllabic or accentual structures, trochees or triads? We assume that syllabic structures are primal, since even in diads that we have had a look at in the first run some kind of iamb could be observed. The trochee "disappears" in some other struc- 
tures of folk verse, too, if the constant is changing its position. Of course, it would be very interesting to observe how the syllabic structures in languages with very different prosodic characteristics, for example, with the left phrasal stress, behave, but such extensive work was never included in the range of our tasks. Nevertheless, we can claim that in exclamations, onomatopoeias, and reduplications of different kinds there are universals, along the lines of which folk verse is built up.

The discovery of rhythm universals as an invariant of a verse is changing the relations between verse and prose fundamentally. Prose, from now on, stops being the baseline, a norm, etc. If we abstract our mind from such anomalies as lipo- and hypermetria, rhythmical inversion, etc., it will be possible to describe the diversity of folk meters with the help of symbols. The suggested formula is an advancement of the digital encoding of A. Potebnya (see Potebnya 1884; for explanations Shtokmar 1952a: 71-76).

An elementary unit of a verse is a colon $\mathbf{k}$, its rhythmical invariant is a ritmema $\rho$. In folklore, all ritmemas come down to two archeritmemas with a 3- and 5-syllable nucleus. Without regard for clausula, we will record them as $\tilde{\boldsymbol{\alpha}}$ and $\tilde{\boldsymbol{\beta}}$, with the account of feminine clausula - as $\boldsymbol{\alpha}$ and $\boldsymbol{\beta}$, masculine clausula - as $\boldsymbol{\alpha}_{-\mathbf{1}}$ and $\boldsymbol{\beta}_{-1}$, and dactylic clausula - as $\boldsymbol{\alpha}_{+1}$ and $\boldsymbol{\beta}_{+1}$. The regularly occurring system of colons - period $\pi$, will be expanded in round brackets (), while the regular combination of periods - stropheme $\sigma$ - in square brackets [] (Fig. 1), just like the irregular combination of periods - strophoids $\mathbf{s}$, and a row of strophes or strophoids that make a text $\xi$ - in curly brackets \{\}. Colons that are smaller than 3 syllables virtually do not exist (see Kvyatkovskiy 1966: 364, 96; Tomashevskiy 1959: 23). However, 1- and 2-syllable commas are often used as the edging of colons (refrains and exclamations), i.e., as subritmemas: $\mathbf{\imath}$ and $\boldsymbol{v}$. In addition to heart-rending romances and the so-called guerrilla songs, regular meters are only observed in folklore in embryonal state, if any. Let us introduce designations for them as well: trochee as it is $\boldsymbol{\varepsilon}$; iamb o; paeons (as doublets $\boldsymbol{\varepsilon}$ and $\mathbf{o}$ ) - 1st $\dot{\mathbf{\eta}}$; 2nd $\dot{\boldsymbol{\omega}}$; 3rd $\mathbf{\eta}$; 4th $\boldsymbol{\omega}$; dactyl $\boldsymbol{\lambda}$; amphibrach $\boldsymbol{\mu}$; anapaest $\mathbf{v}$. The process of transformation of archeritmemas into literary meters remains outside of the scope of this research.

Within this system, $\boldsymbol{\alpha}$ and $\boldsymbol{\beta}$ are the basic units, and $\mathbf{\imath}$ is a minimal unit that is equal to a syllable. In some languages, for example, in monosyllabic $\mathbf{r}$ and v, obviously, belong to the set of basic elements (see Leang 1963; Yan 1976; Slovar' 1974: 127-130, 159). In Turkic languages, where stress is on the last syllable, the colons containing an even number of syllables represent an iambtype conglomeration $\boldsymbol{v}^{2}$, which, however, is easily linked to a trochee-type colon $\mathbf{a}_{-1}$ (see Korogly 1983: 304). Unlike Potebnya's system, this one encodes not only quantitative syllabic parameters, but also qualitative accentual ones - the 
location of the constant and the nature of the clausula - and, at the same time, it conveys the uniformity of the nature of folk verse, which, thus, comes down to combinations and variations of archeritmemas. As an example, I will have a look at the models of some typical strophes from the repertory of Belarusian folklore (words with inversion are marked in italics).

The most popular meter is 8 syllables, which can be observed among the inhabitants of all or almost all parts of the world (Bardavelidze 1975), for example, the Georgian high shairi, which is inclined towards a tetrameter trochee, and the formula is written down both in an expanded and in a short form - [(a $+\alpha)+(\alpha+\alpha)]=[2(\alpha+\alpha)]$ :

\section{Oj, u póli || za haróju \\ Rascie žýta || z liebiadóju}

(PK 1978: 56)

Owing to the abundance of masculine clausulae in the Belarusian language, an 8-syllable unit is often transformed into a 7-syllable one, which is also a frequent phenomenon in Turkic languages (see Akhmetov 1964: 95), while the structure of the nucleus does not change $-\left[\left(\alpha+\alpha_{-1}\right)+\left(\alpha+\alpha_{-1}\right)\right]=\left[\mathbf{2}\left(\alpha+\alpha_{-1}\right)\right]$ :

A na dvare || snieh napáŭ, A malójčyk || z kania spáŭ (PK 1978: 73)

Another ancient meter is a 10-syllable unit with a 5-syllable colon, namely, its version with a masculine clausula: $\left[\left(\boldsymbol{\beta}_{-1}+\boldsymbol{\beta}_{-1}\right)\right]$, which is often observed in the Belarusian calendar-ritual poetry (it is inclined towards trochaic trimeter):

Dzie kaza nahój,

Tam žyta kapój

(ZP 1975: 375).

In East Slavic languages, owing to variable stress, the availability of long words - primarily, of full adjectives, verbs with a postfix -sia, and diminutivehypocoristic forms - the meters with dactylic clausulae, in particular, 10-syllable units, got widespread use $\left[\left(\boldsymbol{a}_{+1}+\boldsymbol{\alpha}_{+1}\right)\right]$ :

$$
\begin{aligned}
& \text { A Kaliádački, } \\
& \text { Bliny-ládački! } \\
& \text { (PZK 1992: 111) }
\end{aligned}
$$

At the end of the eighteenth and beginning of the nineteenth centuries, this 10-syllable unit was canonized as a "Russian meter" for the pasticcio of folklore. 
Sreznevskiy saw a proto-Slavic "epic meter" in it (Sreznevskiy 1959 [1950]: 71-72), but, in the light of the new data, dactylic clausulae outside of the borders of East Slavic languages is an atypical phenomenon (Beyli 2001: 148). It should be pointed out that a similar consistent pattern is also observed in the ontogenesis of a verse: among children, "dactylic rhymes hardly ever occur" (Chukovskiy 2001 [1928]: 276). Quite often, especially in calendar-ritual poetry, which, in comparison with lyric poetry, is less regulated, colons $\boldsymbol{\beta}_{-1}$ and $\boldsymbol{\alpha}_{+1}$ can co-exist in one text: $\boldsymbol{\beta}_{-1}=\boldsymbol{\alpha}_{+1}$, and difference between them becomes prominent only when they are said out loud.

And, finally, one more ancient and simple meter that is widespread not only in Slavic languages, but also far beyond its limits - a 12 -syllable unit with a 6 -syllable colon and a 5-syllable nucleus $[(\boldsymbol{\beta}+\boldsymbol{\beta})+(\boldsymbol{\beta}+\boldsymbol{\beta})]=[2(\boldsymbol{\beta}+\boldsymbol{\beta})]$, which is also inclined towards trochaic trimeter and is popular in literature:

Holub na čaréšni,

Halubka na víšni.

Skažy moj miliéńki,

Što ŭ ciabie na mýsli?

(Fedecki 1992: 27)

More complex formations emerged later on, and their areals were no longer all-encompassing. One of the most widespread complex meters is a 14-syllable unit, which is a combination of the meters described above (it is inclined towards the combination of trochaic trimeter and tetrameter), is typical in folk lyrics, and has exerted an immense effect on literary verse $[(\boldsymbol{\alpha}+\boldsymbol{\alpha}+\boldsymbol{\beta})+(\boldsymbol{\alpha}+$ $\alpha+\beta)]=[2(\alpha+\alpha+\beta)]$ :

Siadzić hólub || na dubóčku,

Halubka na višni.

- Skažy, skažy, || dziaǔčyníca,

Što ŭ ciabie za mýsli?

(PK 1978: 104)

An asymmetrical strophe $\left[\left(\boldsymbol{\beta}_{-1}+\boldsymbol{\beta}_{-1}\right)+\left(\boldsymbol{\alpha}+\boldsymbol{\alpha}+\boldsymbol{\beta}_{-1}\right)\right]$ is a very interesting and even somewhat obscure phenomenon:
A ŭ poli viarbá,
Pad viarboj vadá.
Tam chadzíla, || tam huliála
Dzieǔka maladá
(PK 1978: 60) 
Its modification with feminine clausulae is also typical: $[(\boldsymbol{\beta}+\boldsymbol{\beta})+(\boldsymbol{\alpha}+\boldsymbol{\alpha}+$ $\boldsymbol{\beta})$ ]. It is widespread in West Slavic folk verse (Marčok 1980: 135) as well as in Lithuanian ones (Sauka 1980: 9, 21). It is not used in literature, except for one pasticcio done by Maksim Bahdanovič, which is known to us.

The meters where colons stand in contrast are less typical. Among them, the most popular is the $\boldsymbol{\beta}+\boldsymbol{\alpha}$ type, which is represented by numerous versions, for example, a 10-syllable unit $\left[\left(\boldsymbol{\beta}_{+1}+\alpha\right)+\left(\beta_{+1}+\alpha\right)\right]=\left[2\left(\beta_{+1}+\alpha\right)\right]$ :

\section{U niadzieĺku ránieńka || na zarý \\ Ščabiatala lástaŭka || na mory}

(PK 1978: 50)

The invert correlation of the short and long colons is observed in the meter that is popular in the study of poetry and folklore studies, owing to the attention paid to it by Trubetskoy and Yakobson. It is well-known as a Serbian "deseterets", which is a basic meter in the South Slavic epic. It is current in the West Slavic area as well as among the Lithuanians and Hungarians (Gasparov 2003: 203), and it is quite often used in Belarusian folk lyrics $-[(\boldsymbol{\alpha}+\boldsymbol{\beta})+(\boldsymbol{\alpha}+$ $\beta)]=[2(\alpha+\beta)]$ :

\section{Za tumánam || ničoha nie vídna, Tolki vídna || dúba zielianóha (PK 1978: 80)}

For the first time, this form, along with the "Russian meter", was put forward for the part of the proto-Slavic epic verse by Sreznevskiy, and his idea was picked up by Trubetskoy and Yakobson (Trubetskoy 1987: 356-358; Yakobson 1987: 39-47). The latter even "derived" this meter from the Indo-European 8-syllable unit, and, in turn, he "derived" bylina verse from the "derived" 10-syllable unit. Just like in the case of the Russian meter, Sreznevskiy and his followers were incorrect. I will not cite valid criticism against "deriving" bylina verse from "deseterets", put forward by Zaytsev (1995), but will only point out that the division of meters into epic and lyrical ones in a long-term perspective is inefficient and is not supported by any evidence. There are no reasons to believe that proto-Slavic epos has ever existed, and if it did, the epic traditions that we know about, i.e., Serbian, Russian, and Ukrainian, seem not to be linked to each other. Calendar-ritual poetry provides a more reliable material for reconstructing the ancient verse.

Interestingly enough, in some songs of the Belarusian calendar cycle there is a strophe consisting of colons used in "deseterets", but more complex in composition, with a double 6 -syllable colon and a repetition of a 4-syllable colon at the end of the period as a refrain $-\left[(\boldsymbol{\alpha}+\boldsymbol{\beta}+\boldsymbol{\beta})+{ }^{1} \boldsymbol{\alpha}\right]$ : 


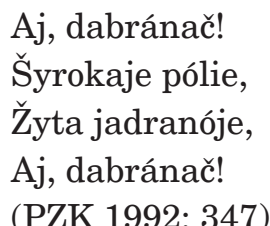

I have not studied well enough the area where this strophe is widely used, but mainly it is linked to the north-eastern part of Belarus.

As for the Russian bylina verse, it possibly dates back to the ancient Slavic 12-syllable $\boldsymbol{\alpha}+\boldsymbol{\alpha}+\boldsymbol{\alpha}$ (in the Turkic tradition - as an 11-syllable $\boldsymbol{v}^{2}+\boldsymbol{v}^{2}+\boldsymbol{\alpha}_{-1}$ ). Here is an example of the strophe where the connection of a 12-syllable unit with an 8-syllable one $-[(\boldsymbol{\alpha}+\mathbf{\alpha}+\mathbf{\alpha})+(\boldsymbol{\alpha}+\mathbf{\alpha}+\mathbf{\alpha})]=[\mathbf{2}(\boldsymbol{\alpha}+\mathbf{\alpha}+\mathbf{\alpha})]$ can be observed:

Viasna krásna, || viasna krásna || nastupáje, Vadoj lúhi, || vadoj lúhi || zaliváje...

(PZK 1992: 181)

If we leave out the repetition of the first colon, we get a typical 8-syllable unit: Viasna krásna / / nastupáje. Let us compare the same transaction in the Turkic language: "It is enough to leave out the first four syllables without detriment to sense, and we are getting a verse consisting of seven syllables" (Korogly 1983: 303).

Veselovskiy (1989: 186) said that epos was genetically linked to lamentations, and Yakobson also stressed this connection in every particular tradition, mainly, in the Serbian and Russian traditions (Yakobson 1987: 39-40). All the more amazing is that he was trying to forcibly narrow down all of those different traditions to a single imaginary source. As for the verse of the Russian lamentations, it lost caesura; after having been modified this way, it started resembling a paeon or an alternating trochee. Loss of caesurae has led to the transformation of the three archeritmemas into a hyperritmema with an 11-syllable nucleus: $\boldsymbol{\alpha}+\boldsymbol{\alpha}+\boldsymbol{\alpha} \rightarrow \boldsymbol{\psi}$. Here is an example of a Russian lamentation where the particle $\partial a$ (in square brackets) enables us to partially trace the "stitches" of the original colons:

Iz-pod réchen'ki plyvét [da] sera útushka, Eta útushka plyvét [da] potikhóshen'ku, Ona khóbody dayét [da] pomaléshen'ku, Goloskóm ona zhupít [da] zhalobnéshen'ko...

(Agreneva-Slavyanskaya 1896: 9-10)

Language places huge pressure on the universals of the rhythm, which leads to the modification of original meters. For example, the 5-syllable colon described 
above in versions $\boldsymbol{\beta}_{-1}$ and $\boldsymbol{\alpha}_{+1}$ has a third version, too, with a shift of constanta to the next-to-last syllable and a formation of a 4-syllable nucleus. Obviously, this pressure was exerted by the Polish language. In this case, there is simply no space for a trochee, and we are getting something like a dactyl as an invariant ( $\left.\mathbf{O o o O}_{0}\right)$ and an iambic dimeter as a variant (oOoOo). Let us designate this dactyl-type ritmema with a ${ }^{\lambda} \boldsymbol{\rho}$; the strophe formula will be $\left[\left({ }^{\lambda} \boldsymbol{\rho}+{ }^{\lambda} \rho\right)+\left({ }^{\lambda} \rho+\right.\right.$ $\left.\left.{ }^{\lambda} \rho\right)\right]=\left[2\left({ }^{\lambda} \rho+{ }^{\lambda} \rho\right)\right]:$

\author{
Dažali žýta || až da daróhi, - \\ Ǔ našaha pána || borzdyja nóhi. \\ Nie žaluj, páni, || bielaha sýru, - \\ Dasć Boh ^ páni || dobraha sýna \\ (BNP 1959: 14)
}

The fate of this meter in folklore and literature is curious indeed (see Paciupa 2014: 154-156). I will not rest upon it for too long, so let us turn to generalizations and outline the problems that crop up in the field of folklore poetry studies in light of the data cited above.

\title{
PERSPECTIVES
}

Firstly, it should be pointed out that binary and trinary rhythmical formations are not limited to the level of syllables, and versified speech cannot be reduced to physiology. "In poetry, measure is not dependent on breathing, it follows the rhythm coming from the brain, not from the lungs" (Terner \& Poppel' 1995: 85). The universals of the rhythm can encompass more complex formations, being included into each other just like nesting dolls. In this case, verse is just one of the manifestations of mental rhythms, or, as it has been pointed out by Alandskiy, "meter is an individual case of a larger psychological phenomenon" (Alandskiy 1875: 81). It should be stressed here that we are nowhere near postulating a "triadic" etc. model of nature, but, on the opposite, we believe that in the course of the cognitive process, an object is forcibly rhythmicized by our brain, which is indisposed to notice the force it is applying. In binary and trinary rhythms, not only the syllables in colons are arranged, but also colons in periods, motifs in plots, etc. A transition to a higher level of organization can be written down by the following formulae: $\boldsymbol{v} \times \mathbf{x}=\mathbf{Y} ; \boldsymbol{\alpha} \times \mathbf{x}=\mathbf{A}$, or $\mathbf{v}^{\mathbf{x}}=\mathbf{Y}$; $\mathbf{a}^{\mathbf{x}}=\mathbf{A}$. The condition of the most ancient poetic text can be represented as $* \boldsymbol{\xi}=*^{\mathbf{n}}$, where $\mathbf{n}=2,3$.

The second important aspect that we should pay attention to is related to the perspectives of the development of the studies of poetry. The discovery of 
rhythmical universals allows us to take a fresh look at verse in terms of time and spatial aspects. While reconstructing the ancient conditions of verse, we should abandon prose-centeredness, where prose is perceived as the norm and verse is regarded as anomaly, and the whole history of verse is seen as a process of the "harmonization of prose". With such an attitude in mind, conclusions are made without due consideration of the conditions of the language, and more precisely, on the basis of one or another model of speech that is developed enough. Verse is dependent on the prosodic setting, in which universals are actualized. Another error made during reconstruction is the projection of the rules of development of literary verse onto folk verse. The revolutionary conclusions made by Perry and Lord are not taken into consideration: "An oral piece of writing is not created for performing it, it is created in the process of performing" (Lord 1994: 24). In folk verse, there is no loss of rhythm that would not be compensated for at the moment of its reproduction. But we should bear in mind that, in addition to rhythm universals, there are also some rhythmical stereotypes that keep migrating in the process of cultural exchange until they collide with a specific prosody.

Penetration into the layers of time is unthinkable without mapping the geography of meters. Instead of pinning the labels, such as "accentual" and "syllabic", and wandering into the maze of statistics of inter-ictus intervals, which is pointless if there is no clear vision of an invariant, instead of endless arguments about theories, each one of which is right in its own way, the study of poetry should eventually resort to the cataloguing of folk verse with due consideration of the areas of distribution of this or that form within a national and international scale, with a perspective of tracing isoglosses. The essential support within the context of comparative metrics can be provided by comparative studies of exclamations and onomatopoeias, which was highlighted by Jakobowski (see Jakobowski 1891). We are distancing ourselves from Bowwow and Pooh-pooh theories, but in interjections and onomatopoeias we see the enclaves, in a similar way to earlier stages of cultural development, which still contain features hidden in more complex language subsystems.

\section{ACKNOWLEDGEMENTS}

The article was written as part of a project financed by the Foreign Ministry of Estonia through the Developmental Cooperation Programme (66-2015-A). 


\section{NOTES}

1 Herein the term syntagma should be seen as a "fragment of a speech chain, a part of a phrase" (i.e., a syntagma according to Shcherba, not according to de Saussure).

2 As for the term line, which is sometimes promoted as the underlying category of verse, it is irrelevant to folk verse: firstly, it can accommodate one colon or the entire period, and, secondly, one way or another, it is an interpretation of a folklorist.

3 Every single letter denotes a syllable: a small letter 'o' means an unstressed syllable; a capital letter ' $O$ ' means a slightly stressed syllable, a capital bold letter 'O' means strongly stressed syllable; $x$ means a varying number $(0-1-2 \ldots)$ of clausula syllables; two vertical lines || mean a caesura; slash and backslash characters $/ \backslash$ mean a leymah.

4 This term was first used by Yanakiev (1960: 89-95), but with a completely different meaning.

5 Neither a clausula nor an anacrusis are included in a nucleus, according to Yanakiev (1960: 95), or in a metric sequence, according to Tomashevskiy (1923: 46), which, in my opinion, is inappropriate, since everything that is happening to the left of the constant is a single whole field of rhythmic strain. If the nucleus does not include the anacrusis, the notion of the nucleus will lose its explanatory power.

6 Recently, interest in similar structures among philosophers has been revived. For example, a huge amount of culturological material has been collected and generalized in a book by Borzova (2007). But, unfortunately, philosophical research in this field quite often indulges in essentialism and mysticism.

\section{REFERENCES}

Agreneva-Slavyanskaya, Ol'ga 1896 [1887]. Opisanie russkoi krest'ianskoi svad'by s tekstom i pesniami: obriadovymi, golosil'nymi, prichital'nymi i zavyval'nymi. [Description of Russian Farmers' Wedding with the Text and Songs: Ritual, Crying, Wailing, Lamentative.] In 3 vols. Vol 2. Opisanie vsekh obriadov svadebnogo dnia. [Description of the Wedding Day Rituals.] Tver': n.p.

Akhmetov, Zaki 1964. Kazakhskoe stikhoslozhenie: Problemy razvitiia stikha $v$ dorevoliutsionnoi $i$ sovremennoi poezii. [Kazakh Versification (Problems of Verse Development in Prerevolutionary and Modern Poetry).] Alma-Ata: Nauka.

Alandskiy, Pavel 1875. Poeziia kak predmet nauki. [Poetry as a Subject of Science.] Universitetskie izvestiia, No. 2, Chast' neofitsial'naya, pp. 71-129.

Bardavelidze, Dzhondo 1975. K izucheniiu drevneishikh stikhotvornykh form. [To the Study of the Most Ancient Poetic Forms.] In: N. Kravtsov (ed.) Problemy fol'klora. Moscow: Nauka, pp. 191-197.

Beyli, Dzheims 2001. Izbrannye stat'i po russkomu narodnomu stikhu. [Selected Articles on Russian Folk Verse.] Moscow: Iazyki russkoi kul'tury.

BNP 1959 = Bielaruskija narodnyja piesni. [Belarusian Folk Songs.] Minsk: Dziaržaŭnaje vydaviectva BSSR. 
Bondarko, Liia \& Verbitskaia, Liudmila \& Gordina, Mirra 1991. Osnovy obshchei fonetiki: Uchebnoe posobie. [Foundations of General Phonetics: Manual.] St. Petersburg: Izd-vo Sankt-Peterburgskogo universiteta.

Borzova, Elena 2007. Triadologiia. [Triadology.] St. Petersburg: SPbGUKI.

Chudovskiy, Valerian 1915. Neskol'ko myslei k vozmozhnomu ucheniiu o stikhe (s primernym razborom stikhoslozheniia v I glave "Evgeniia Onegina"). [Several Thoughts about the Possibility of Verse Teaching (On the Example of Versification Analysis in the First Chapter of "Evgeniy Onegin").] Apollon, No. 8-9, pp. 55-95. Available at http://www.v-ivanov.it/apollon/apollon_1915_08-09.pdf, last accessed on 28 May 2018.

Chudovskiy, Valerian 1917. Neskol'ko utverzhdenii o russkom stikhe. [Several Statements about Russian Verse.] Apollon, No. 4-5, pp. 58-69. Available at http:// www.v-ivanov.it/apollon/apollon_1917_04-05.pdf, last accessed on 28 May 2018.

Chukovskiy, Korney 2001 [1928]. Ot dvukh do piati. [From Two to Five.] Sobranie sochinenii $v 15$ t. Vol. 2. Moscow: Terra \& Knizhnyi klub. Available at http:// www.chukfamily.ru/kornei/prosa/knigi/onetofive, last accessed on 28 May 2018.

Dubenskiy, Dmitriy 1828. Opyt o narodnom russkom stikhoslozhenii. [Experience of Folk Russian Versification.] Moscow: Universitetskaia tipografiia.

Fedecki, Ziemowit 1992. Cioplyja viečary... dy chalodnyja ranki... czyli Co śpiewano $w$ Feliksowie: (bielaruskija narodnyja piesni Lidskaha pavietu). [Belarusian Folk Songs of Lida District.] Warszawa: Białoruskie towarzystwo społeczno-kulturalne.

Gasparov, Mikhail 2003. Ocherk istorii evropeiskogo stikha. [Essay of European Verse History.] Moscow: Fortuna Limited.

Gasparov, Mikhail \& Skulacheva, Tat'iana 2004. Stat'i o lingvistike stikha. [Articles about Linguistics of Verse.] Moscow: Iazyki slavianskoi kul'tury.

Ivanov, Vyacheslav \& Toporov, Vladimir 1963. K rekonstruktsii praslavianskogo teksta. [To the Reconstruction of Proto-Slavic Text.] Slavianskoe Iazykoznanie: Doklady sovetskoi delegatsii. V Mezhdunarodnyi S"ezd Slavistov (Sofiia, sentiabr' 1963). Moscow: Izdatel'stvo AN SSSR, pp. 88-158. Available at http://www.pseudology. org/Literature/5_Siezd_Slavyanskoe_Yazykoznanie_1963a.pdf, last accessed on 28 May 2018.

Jakobowski, Ludwig 1891. Die Anfänge der Poesie: Grundlegung zu einer realistischen Entwickelungsgeschichte der Poesie. Dresden \& Leipzig: E. Pierson's Verlag. Available at https://archive.org/details/dieanfngederpoe01jacogoog, last accessed on 28 May 2018.

Kodzasov, Sandro \& Krivnova, Ol'ga 2001. Obshchaia fonetika: Uchebnik. [General Phonetics: Textbook.] Moscow: Izd-vo Rossiiskogo gosudarstvennogo gumanitarnogo universiteta.

Korogly, Khalyk 1983. Vzaimosviazi eposa narodov Srednei Azii, Irana i Azerbaidzhana. [Interconnections of Eposes of Middle Asia, Iran and Azerbaijan Peoples.] Moscow: Nauka.

Kulakovskiy, Yulian 1890. K voprosu o russkom narodnom stikhe. [To the Issue of Russian Folk Verse.] Chteniia $v$ istoricheskom obshchestve nestora letopistsa. Vol. 4. Kiev: Tipografiia V.I. Zavadszkago, pp. 1-3. Available at http://history.org. ua/LiberUA/ChtenIONL4_1890/ChtenIONL4_1890.pdf, last accessed on 28 May 2018 . 
Kvyatkovskiy, Aleksandr 1966. Poeticheskii slovar'. [Poetical Vocabulary.] Moscow: Sovetskaia entsiklopediia.

Kvyatkovskiy, Aleksandr 2008. Ritmologiia. [Rhythmology.] St. Petersburg: INAPRESS \& Izdatel'stvo Dmitrii Bulanin.

Leang, Khap An 1963. Elementy kkhmerskogo stikhoslozheniia. [Elements of Khmer Versification.] Narody Azii i Afriki, Vol. 6, pp. 130-139.

Lord, Al'bert 1994. Skazitel'. [Storyteller.] Transl. and commented by Iu. Kleiner \& G. Levinton. Moscow: Izdatel'skaia firma Vostochnaia literatura RAN.

Marčok, Viliam 1980. Estetika a poetika l'udovej poézie. [Aesthetics and Poetics of Folk Poetry.] Bratislava: Tatran.

Paciupa, Jury 2004. Strala Zienona: Rytmalahičny traktat. [Zenon's Arrow: Rhythmological Tractate.] Arche, Vol. 5, pp. 262-319.

Paciupa, Jury 2014. Rytmavyja struktury bielaruskaj narodnaj piesni: Podstupy da prabliemy (na materyjalie v. Damejki Lidskaha rajona). [Rhythmic Structures of Belarusian Folk Song: Approach to the Issue, on the Data of Dameiki Village, Lida District).] Bielaruski falklor: Materyjaly i dasliedavanni: Zbornik navukovych prac. Minsk: Bielaruskaja navuka, Vol. 1, pp. 137-161.

Paciupa, Jury 2014-2016. Zakony rytmu i pryroda vykličnikaŭ. [Laws of Rhythm and Nature of Interjections.] Rodnaje slova, 2014: Vol. 8, pp. 23-26; Vol. 9, pp. 22-25; Vol. 11, pp. 19-24; 2015: Vol. 1, pp. 29-34; Vol. 4, pp. 25-31; 2016: Vol. 2, pp. 18-23.

Paciupa, Jury 2016. Vieršavannie ŭ zamovach: Pavodlie materyjalaŭ Viciebščyny i Hrodzienščyny. [Versification in Spells According to the Materials of Vitsebsk and Hrodna Regions.] Bielaruski faĺlklor: Materyjaly $i$ dasliedavanni: Zbornik navukovych prac. Minsk: Biel. navuka, Vol. 3, pp. 146-197.

PK 1978 = Piesni pra kachannie. [Songs about Love.] Minsk: Navuka i technika.

Polivanov, Yevgeniy 1963. Obshchii foneticheskii printsip vsiakoi poeticheskoi tekhniki.

[General Phonetic Principle of Any Poetical Technique.] Voprosy iazykoznaniia, Vol. 1, pp. 99-112. Available at http://www.ruslang.ru/doc/voprosy/voprosy1963-1. pdf, last accessed on 29 May 2018.

Potebnya, Aleksandr 1884. Obzor poeticheskikh motivov koliadok i shchedrivok. I: Razmer. [Overview of Poetical Motifs of Carols and Pre-New Year Songs. I: Meter.] Russkii filologicheskii vestnik, Vol. 11, No. 1, pp. 1-32.

Propp, Vladimir 2001. Morfologiia volshebnoi skazki. [Morphology of the Fairytale.] Moscow: Labirint.

PZK 1992 = Paezija bielaruskaha ziemliarobčaha kaliendara. [Poetry of Belarusian Agricultural Calendar.] Minsk: Navuka i technika.

Samsonov, Dormidont 1817. Kratkoe rassuzhdenie o russkom stikhoslozhenii. [Brief Speculation about Russian Versification.] Vestnik Evropy, Vol. 15-16, pp. 219-253.

Sauka, Leonardas Yonovich 1980. Stikhoslozheniye litovskikh narodnykh pesen. Avtoreferat dissertatsii na soiskanie uchenoi stepeni doktora filologicheskikh nauk. [Versification of Lithuanian Folk Songs. Author's Abstract of the Dissertation for the Scientific Degree of PhD.] Vilnius: n.p.

Shtokmar, Mikhail 1952a. Issledovaniia v oblasti russkogo narodnogo stikhoslozheniia. [Research in the Field of Russian Folk Versification.] Moscow: Izd-vo Akademii nauk SSSR. 
Shtokmar, Mikhail 1952b. O stikhovoi sisteme Maiakovskogo. [About the Verse System of Mayakovsky.] Tvorchestvo Maiakovskogo: Sbornik statei. Moscow: Izdatel'stvo Akademii nauk SSSR, pp. 258-312.

Slovar' $1974=$ Slovar' literaturovedcheskikh terminov. [Dictionary of Terms in Literature Studies.] Edited \& compiled by L. Timofeev \& S. Turaev. Moscow: Prosveshchenie.

Sreznevskiy, Izmail 1959 [1850]. Mysli ob istorii russkogo iazyka (chitano na akte Imperatorskogo S. Peterburgskogo universiteta, 8-go fevralia 1849 goda). [Thoughts about the History of the Russian Language (Reported at the Sitting of Imperial St. Petersburg University on 8 February 1849).] Moscow: Gosudarstvennoe uchebno-pedagogicheskoe izdatel'stvo.

Taranovskiy, Kirill 2000. O poezii $i$ poetike. [About Poetry and Poetics.] Compiled by M. Gasparov. Moscow: Iazyki russkoi kul'tury.

Taranovskiy, Kirill 2010. Russkie dvuslozhnye razmery: Stat'i o stikhe. [Russian Disyllabic Meters: Articles about Verse.] Moscow: Iazyki slavyanskoi kul'tury.

Terner, Frederik \& Poppel', Ernst 1995. Poeziia, mozg i vremia. [Poetry, Brain and Time.] Krasota i mozg: Biologicheskie aspekty estetiki. Moscow: Mir, pp. 74-96.

Timofeyev, Leonid 1958. Ocherki teorii i istorii russkogo stikha. [Essays of Russian Verse Theory and History.] Moscow: Gosudarstvennoe izdatel'stvo khudozhestvennoi literatury.

Timofeyev, Leonid 1987. Slovo v stikhe: Monografiia. [Word in Verse: Monograph.] Moscow: Sovetskii pisatel'.

Tomashevskiy, Boris 1923. Russkoe stikhoslozhenie: metrika. [Russian Versification: Metrics.] St. Petersburg: Izdatel'stvo Akademiia.

Tomashevskiy, Boris 1959. Stikh i iazyk: Filologicheskie ocherki. [Verse and Language: Philological Essays.] Moscow \& Leningrad: Gosudarstvennoye izdatel'stvo khudozhestvennoi literatury.

Trediakovskiy, Vasiliy 2002. Sposob k slozheniiu rossiiskikh stikhov, protiv vydannogo v 1735 gode ispravlennyi i dopolnennyi. [The Way to Russian Versification, Corrected and Supplemented Edition of 1735.] In: A. Ranchin \& V. Korovin (comps.) Kritika XVIII veka. Moscow: Olimp \& AST, pp. 109-147.

Trubetskoy, Nikolay 1987. Izbrannye trudy po filologii: Perevody. [Selected Works on Philology: Translations.] Moscow: Progress.

Tudenov, Gunga 1958. Buriatskoe stikhoslozhenie: ritmicheskaia organizatsiia buriatskikh stikhov. [Buryat Versification: Rhythmic Organization of Buryat Verses.] Ulan-Ude: Buriatskoe knizhnoe izdatel'stvo.

Veselovskiy, Aleksandr 1989. Istoricheskaia poetika. [Historical Poetics.] Moscow: Vysshaia shkola.

Vostokov, Aleksandr 1817. Opyt o russkom stikhoslozhenii. [An Experience of Russian Versification.] St. Petersburg: Morskaia Tipografiia.

Yakobson, Roman 1923. O cheshskom stikhe: preimushchestvenno v sopostavlenii s russkim. [About Czech Verse Mainly in Comparison with the Russian One.] Moscow: Gosudarstvennoe izdatel'stvo.

Yakobson, Roman 1987. Raboty po poetike: Perevody. [Works on Poetics: Translations.] Moscow: Progress. 
Yanakiev, Miroslav 1960. Bŭlgarsko stikhoznanie. [Bulgarian Versification.] Sofia: Nauka i izkustvo.

Yan, K. 1976. O kharaktere metricheskoi sistemy v'etnamskogo stikhoslozheniia. [About the Character of the Metric System of Vietnamese Versification.] In: Souremennaia literatura zarubezhnogo Vostoka. Tashkent: n.p., pp. 98-110.

Zaytsev, Aleksandr 1995. Stikh russkoi byliny i praindoevropeiskaia poeziia. [Verse of Russian Epic and pro-Indo-European Poetry.] In: T. Novichkova (ed.) Russkii fol'klor. Vol. 28: Epicheskie traditsii. St. Petersburg: Nauka, pp. 198-205.

ZP 1975 = Zimovyja piesni: kaliadki $i$ ščadroǔki. [Winter Songs: Carols and Pre-New Year Ones.] Minsk: Navuka i technika. 